\title{
Overexpression of PARP is an independent prognostic marker for poor survival in Middle Eastern breast cancer and its inhibition can be enhanced with embelin co-treatment
}

\author{
Abdul Khalid Siraj ${ }^{1, *}$, Poyil Pratheeshkumar ${ }^{1, *}$, Sandeep Kumar Parvathareddy ${ }^{1}$, \\ Sasidharan Padmaja Divya ${ }^{1}$, Fouad Al-Dayel ${ }^{2}$, Asma Tulbah², Dahish Ajarim ${ }^{3}$ and \\ Khawla S. Al-Kuraya ${ }^{1}$ \\ ${ }^{1}$ Human Cancer Genomic Research, King Faisal Specialist Hospital and Research Center, Riyadh, Saudi Arabia \\ ${ }^{2}$ Department of Pathology, King Faisal Specialist Hospital and Research Centre, Riyadh, Saudi Arabia \\ ${ }^{3}$ Department of Oncology Centre, King Faisal Specialist Hospital and Research Centre, Riyadh, Saudi Arabia \\ *These authors have contributed equally to this work
}

Correspondence to: Khawla S. Al-Kuraya, email: kkuraya@kfshrc.edu.sa

Keywords: PARP; XIAP; breast cancer; olaparib and embelin

Received: September 05, $2018 \quad$ Accepted: December 04, $2018 \quad$ Published: December 18, 2018

Copyright: Siraj et al. This is an open-access article distributed under the terms of the Creative Commons Attribution License 3.0 (CC BY 3.0), which permits unrestricted use, distribution, and reproduction in any medium, provided the original author and source are credited.

\section{ABSTRACT}

\begin{abstract}
Patients with aggressive breast cancer (BC) subtypes usually don't have favorable prognosis despite the improvement in treatment modalities. These cancers still remain a major cause of morbidity and mortality in females. This has fostered a major effort to discover actionable molecular targets to treat these patients. Poly ADP ribose polymerase (PARP) is one of these molecular targets that are under comprehensive investigation for treatment of such tumors. However, its role in the pathogenesis of BC from Middle Eastern ethnicity has not yet been explored. Therefore, we examined the expression of PARP protein in a large cohort of over 1000 Middle Eastern BC cases by immunohistochemistry. Correlation with clinicopathological parameters were performed. Nuclear PARP overexpression was observed in $44.7 \%$ of all BC cases and was significantly associated with aggressive clinicopathological markers. Interestingly, nuclear PARP overexpression was an independent predictor of poor prognosis. PARP overexpression was also directly associated with XIAP overexpression, with PARP and XIAP co-expression in $15.8 \%(159 / 1008)$ of our cases. We showed that combined inhibition of PARP by olaparib and XIAP by embelin significantly and synergistically inhibited cell growth and induced apoptosis in BC cell lines. Finally, co-treatment of olaparib and embelin regressed BC xenograft tumor growth in nude mice. Our results revealed the role of PARP in Middle Eastern BC pathogenesis and prognosis. Furthermore, our data support the potential clinical development of combined inhibition of PARP and XIAP, which eventually could extend the utility of olaparib beyond BRCA deficient cancer.
\end{abstract}

\section{INTRODUCTION}

Breast cancer is a leading cause of morbidity and mortality in women worldwide. In Saudi Arabia, BC is the most common cancer among females, accounting for $28.7 \%$ of newly diagnosed female cancers and the incidence continues to increase every year [1]. BC is a heterogeneous disease containing several subgroups with molecular signature [2]. Triple negative breast cancer (TNBC) is the most aggressive histological subtype of BC representing $15-20 \%$ of all BCs with a high potential for metastasis and resistance to standard therapies $[3,4]$. Therefore, identifying molecular therapeutic target for aggressive and metastatic BC is warranted.

Poly (ADP-ribose) polymerases (PARPs) are a family of enzymes that share a catalytic PARP homology 
domain and the ability to poly (ADP-ribosyl)ate protein substrate $[5,6]$. PARP proteins involved in a number of cellular processes including transcriptional regulation, DNA repair, cell survival, cell division, apoptosis, maintenance of genomic stability and telomere integrity [7, 8]. PARP-1 is the most abundant member as well as bestcharacterized DNA repair enzyme of PARP super family and is responsible for the majority of PARP activity in the cell [9]. PARP-1 protein overexpression has been reported in various human malignancies, including BC [10-14]. PARP inhibitors target DNA repair defects in hereditary BC [15]. PARP inhibitors as monotherapy or in combination therapy have yielded promising results against different cancers in recent clinical trials [16]. Olaparib is an orally active PARP inhibitor that selectively kills cancer cells with deficient $B R C A 1$ and $B R C A$ 2, which encode proteins known to function in DNA repair through homologous recombination (HR) $[17,18]$. However, $B R C A-$ mutant tumors represent only a small fraction $(2-3 \%)$ of all BCs [19] and only $12.5 \%$ of TNBCs [20], which might limit the therapeutic use of PARP inhibitor monotherapies.

$\mathrm{X}$-linked inhibitor of apoptosis protein (XIAP) has been found to be a promising therapeutic molecular target in Middle Eastern BC and other cancers [21-23]. The main role of XIAP is to disrupt and inhibit apoptosis by acting at caspase 3 and -7 via the second BIR domain and caspase 9 via the third BIR domain [24-26]. We have demonstrated previously the efficacy of non-peptide small molecule inhibitor embelin on inducing apoptosis in BC cell line by binding to the BIR3 domain of XIAP and blocking the interaction of XIAP with caspase to promote apoptosis [21]. Although many combination therapies involving PARP inhibitors are being investigated [27-30], the effect of co-targeting both PARP and XIAP in BC has not yet been explored.

In this study, we first investigated the expression of PARP protein in more than 1000 Middle Eastern BC cases and their clinico-pathological correlations including patient survival. Then, we were able to demonstrate the superiority and synergism of inhibition of PARP (using olaparib) and XIAP (using embelin) together over using single inhibitor alone. This synergistic effect on cell proliferation, apoptosis and tumor growth is demonstrated both in vitro and in vivo. These data clearly demonstrate that PARP plays a significant role in the Middle Eastern $\mathrm{BC}$ pathogenesis and its combined inhibition with XIAP may expand the role of PARP inhibition therapy beyond $B R C A$-deficient BCs.

\section{RESULTS}

\section{PARP over-expression in $\mathrm{BC}$ clinical cases and association with clinico-pathological parameters}

PARP expression was analysed in 1008 breast cancer cases using tissue microarray. Nuclear PARP over-expression was noted in $44.7 \%(451 / 1008)$ of the cases (Table 1, Figure 1). PARP over-expression was associated with aggressive clinical parameters such as larger tumor size $(p=0.0136)$, distant metastasis $(p=0.0003)$, stage IV tumors $(p=0.0006)$, grade 3 tumors $(p<0.0001)$ and triple negative breast cancers $(p<0.0001)$. PARP over-expression was also found to be associated with proliferative marker Ki-67 $(p<0.0001)$ and anti-apoptotic marker XIAP $(p<0.0001)$. More importantly, PARP over-expression was significantly associated with poor 5-year overall survival ( $p=0.0006)$ (Table 2, Supplementary Figure 1). On multivariate analysis, using Cox proportional hazards regression model, we found that PARP over-expression was an independent prognostic factor $(\mathrm{HR}=1.43 ; 95 \% \mathrm{CI}=1.01-2.04$; $p=0.0428$ ) (Table 2). Interestingly, PARP and XIAP were co-expressed in $15.8 \%(159 / 1008)$ of our cases.

\section{Olaparib and embelin synergistically induced apoptosis in $\mathrm{BC}$ cells}

Our clinical data showed that PARP overexpression was directly associated with the overexpression of antiapoptotic protein, XIAP. Therefore, we sought to determine whether co-targeting of PARP and XIAP using specific pharmacological inhibitors, could inhibit $\mathrm{BC}$ growth in vitro. $\mathrm{BC}$ cells were incubated with and without indicated doses of olaparib or embelin for 48 hours; cell viability was determined by MTT assay. Olaparib treatment caused mild effect on cell viability (Figure 2A), whereas embelin alone showed a dose-dependent inhibition of cell viability in BC cells (Figure 2B). Combination of different doses of olaparib with sub-optimal dose of embelin synergistically inhibited cell viability in $\mathrm{BC}$ cells (Figure 2C). Using Chou and Talalay method and Calcusyn software [31], we found that olaparib at $1 \mu \mathrm{M}$ and embelin at $5 \mu \mathrm{M}$ had a combination Index (CI) of 0.298 (strong synergism) in MDA-MB-231 cell line (Supplementary Figure 2) and 0.358 (synergism) in CAL-120 cell line (Supplementary Figure 3) suggesting a synergistic inhibition of cell viability. We selected these doses for further experimentations. Next, to determine whether inhibition of cell viability was due to induction of apoptosis, BC cells were treated with olaparib and embelin either alone or combination for 48 hours and cells were stained with annexin V/PI dual staining and analyzed by flow cytometry. In MDA-MB-231 cells, olaparib or embelin alone induced $14.4 \pm 1.1 \%$ or $17.1 \pm 0.6 \%$ apoptosis, respectively, whereas co-treatment with olaparib and embelin exposure significantly increased the apoptotic population to $50.7 \pm 1.5 \%(p<0.05)$. A similar synergistic effect was also observed in CAL-120 cells (Figure 2D).

\section{Olaparib but not embelin activates caspase-8 mediated extrinsic apoptotic signaling pathway in $\mathrm{BC}$ cells}

Since caspase- 8 plays a pivotal role in the extrinsic apoptotic signaling pathway [32], we investigated whether 
Table 1: Correlation of PARP protein expression with clinico-pathological parameters in breast cancer

\begin{tabular}{|c|c|c|c|c|c|c|c|}
\hline \multirow[b]{3}{*}{ Total number of cases } & \multicolumn{2}{|c|}{ Total } & \multicolumn{2}{|c|}{ High expression } & \multicolumn{2}{|c|}{ Low expression } & \multirow[t]{3}{*}{$p$ value } \\
\hline & $N$ & $\%$ & $N$ & $\%$ & $N$ & $\%$ & \\
\hline & 1008 & & 451 & 44.7 & 557 & 55.3 & \\
\hline \multicolumn{8}{|l|}{ Age Groups } \\
\hline$\leq 50$ & 686 & 68.1 & 305 & 44.5 & 381 & 55.5 & 0.7931 \\
\hline$>50$ & 322 & 31.9 & 146 & 45.3 & 176 & 54.7 & \\
\hline \multicolumn{8}{|l|}{ Tumor size } \\
\hline $\mathrm{T} 1$ & 219 & 22.2 & 82 & 37.4 & 137 & 62.6 & 0.0136 \\
\hline $\mathrm{T} 2$ & 495 & 50.3 & 218 & 44.0 & 277 & 56.0 & \\
\hline T3 & 145 & 14.7 & 75 & 51.7 & 70 & 48.3 & \\
\hline $\mathrm{T} 4$ & 126 & 12.8 & 66 & 52.4 & 60 & 47.6 & \\
\hline \multicolumn{8}{|l|}{ Lymph Nodes } \\
\hline No & 312 & 33.0 & 133 & 42.6 & 179 & 57.4 & 0.6011 \\
\hline N1 & 305 & 32.3 & 134 & 43.9 & 171 & 56.1 & \\
\hline N2 & 197 & 20.8 & 87 & 44.2 & 110 & 55.8 & \\
\hline N3 & 131 & 13.9 & 65 & 49.6 & 66 & 50.4 & \\
\hline \multicolumn{8}{|l|}{ Metastasis } \\
\hline M0 & 917 & 91.0 & 394 & 43.0 & 523 & 57.0 & 0.0003 \\
\hline M1 & 91 & 9.0 & 57 & 62.6 & 34 & 37.4 & \\
\hline \multicolumn{8}{|l|}{ Tumour Stage } \\
\hline I & 87 & 9.0 & 32 & 36.8 & 55 & 63.2 & 0.0006 \\
\hline II & 407 & 42.1 & 165 & 40.5 & 242 & 59.5 & \\
\hline III & 381 & 39.5 & 177 & 46.5 & 204 & 53.5 & \\
\hline IV & 91 & 9.4 & 57 & 62.6 & 34 & 37.4 & \\
\hline \multicolumn{8}{|l|}{ Histological Grade } \\
\hline Well differentiated & 81 & 8.1 & 21 & 25.9 & 60 & 74.1 & $<0.0001$ \\
\hline Moderately differentiated & 511 & 51.3 & 205 & 40.1 & 306 & 59.9 & \\
\hline Poorly differentiated & 405 & 40.6 & 224 & 55.3 & 181 & 44.7 & \\
\hline \multicolumn{8}{|l|}{ Histology } \\
\hline Infiltrating Ductal Carcinoma & 917 & 93.7 & 421 & 45.9 & 496 & 54.1 & 0.2681 \\
\hline Infiltrating Lobular & 46 & 4.7 & 16 & 34.8 & 30 & 65.2 & \\
\hline Mucinous $\mathrm{Ca}$ & 16 & 1.6 & 6 & 37.5 & 10 & 62.5 & \\
\hline \multicolumn{8}{|l|}{ Lymphovascular invasion } \\
\hline Yes & 373 & 41.7 & 173 & 46.4 & 200 & 53.6 & 0.6135 \\
\hline No & 521 & 58.3 & 233 & 44.7 & 288 & 55.3 & \\
\hline \multicolumn{8}{|l|}{ Triple Negative } \\
\hline No & 851 & 85.1 & 348 & 40.9 & 503 & 59.1 & $<0.0001$ \\
\hline Yes & 149 & 14.9 & 101 & 67.8 & 48 & 32.2 & \\
\hline \multicolumn{8}{|l|}{ Ki-67 IHC } \\
\hline High & 624 & 63.5 & 331 & 53.0 & 293 & 47.0 & $<0.0001$ \\
\hline Low & 358 & 36.5 & 112 & 31.3 & 246 & 68.7 & \\
\hline \multicolumn{8}{|l|}{ XIAP } \\
\hline High & 284 & 29.5 & 159 & 56.0 & 125 & 44.0 & $<0.0001$ \\
\hline Low & 680 & 70.5 & 276 & 40.6 & 404 & 59.4 & \\
\hline \multicolumn{8}{|l|}{ Survival } \\
\hline OS 5 Years & & & & 73.1 & & 85.6 & 0.0006 \\
\hline
\end{tabular}


treatment of olaparib and embelin causes activation of caspase- 8 and Bid truncation in BC cells. BC cells were treated with olaparib $(1 \mu \mathrm{M})$ and embelin $(5 \mu \mathrm{M})$ either alone or combination for 48 hours and western blot analysis was performed using antibodies against caspase-8. As shown in Figure 3A, treatment of olaparib markedly activated caspase- 8 , whereas embelin has no effect on caspase- 8 activation. In order to confirm the role of caspases-8 in olaparib and embelin induced apoptosis, BC cells were pre-treated with specific caspase- 8 inhibitor, z-IETD-fmk $(80 \mu \mathrm{M})$ for three hours followed by treatment with olaparib, embelin and combination for 48 hours. As shown in Figure 3B, there was appreciable inhibition of apoptosis in z-IETD-fmk pre-treated cells as compared to olaparib and embelin co-treated cells alone. In addition, caspase- 8 inhibition by z-IETD-fmk significantly inhibited olaparib induced apoptosis, whereas z-IETDfmk has no effect on embelin induced apoptosis (Figure $3 \mathrm{~B})$. These data clearly indicated that olaparib induces caspase- 8 mediated apoptosis but not embelin in $\mathrm{BC}$ cells. Treatment with olaparib and embelin synergistically induced activation and cleavage of Bid, Caspase-9, Caspase-3 and PARP in both cell lines tested (Figure 3C). Truncated Bid translocate to the mitochondrial membrane to activate $\mathrm{Bax}$ or Bak and inactivate anti-apoptotic proteins such as Bcl-2 and Bcl-xl, resulting in the release of cytochrome c $[33,34]$. Co-treatment of olaparib and embelin truncated Bid and down-regulated the expression of Bcl-2 and Bcl-Xl in both the cell lines tested (Figure 3D). Olaparib and embelin synergistically down-regulated the inhibitor of apoptosis proteins (IAPs), cIAP1, XIAP and Survivin, that play an important role in inhibition of apoptosis (Figure 3D). We then determined the effect of truncation of Bid on Bax activation. We co-treated with olaparib and embelin for different time periods in BC cell lines. We found evidence that Bax protein underwent conformational changes at 8 hours in both $\mathrm{BC}$ cell lines (Figure 4A). We next determined whether conformational changes in Bax protein caused change in mitochondrial membrane potential, the early event of activation of

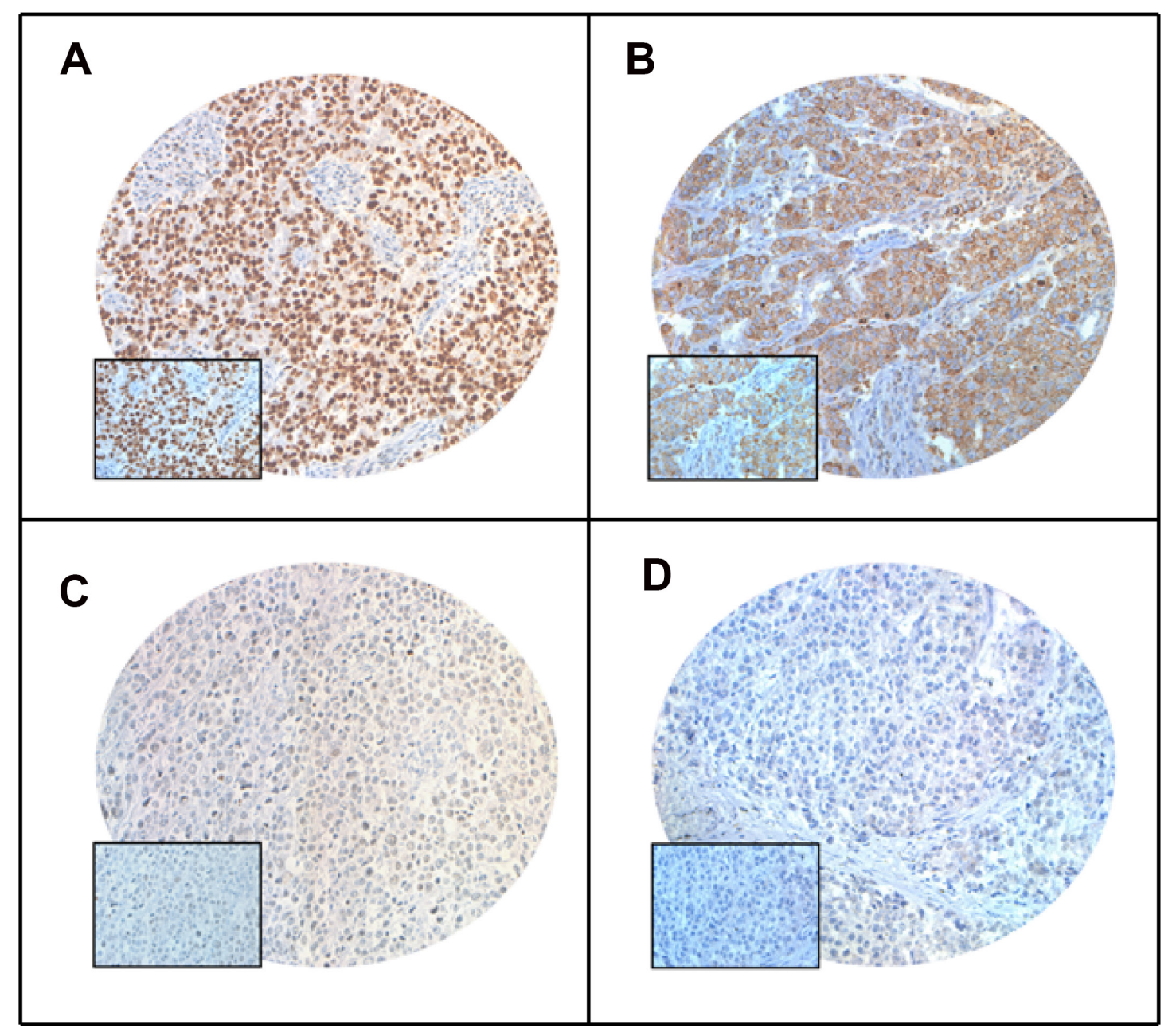

Figure 1: Tissue microarray based immunohistochemistry analysis of PARP and XIAP in breast cancer (BC) patients. BC TMA spots showing overexpression of PARP (A) and XIAP (B). In contrast, another set of TMA spots showing reduced expression of PARP (C) and XIAP (D). 20 X/0.70 objective on an Olympus BX 51 microscope. (Olympus America Inc, Center Valley, PA, USA) with the inset showing a $40 \times 0.85$ aperture magnified view of the same TMA spot. 
Table 2: Univariate and multivariate analysis of PARP using Cox proportional hazard model

\begin{tabular}{|c|c|c|c|c|}
\hline \multirow[t]{2}{*}{ Clinical parameters } & \multicolumn{2}{|c|}{ Univariate } & \multicolumn{2}{|c|}{ Multivariate } \\
\hline & Risk ratio $(95 \% \mathrm{CI})$ & $p$ value & Risk ratio $(95 \% \mathrm{CI})$ & $p$ value \\
\hline $\begin{array}{l}\text { Age } \\
\text { Above }>50\end{array}$ & $0.93(0.67-1.28)$ & 0.6678 & $0.84(0.58-1.18)$ & 0.3158 \\
\hline $\begin{array}{l}\text { Stage } \\
\text { IV }\end{array}$ & $7.04(4.96-9.85)$ & $<0.0001$ & $4.85(3.31-7.10)$ & $<0.0001$ \\
\hline $\begin{array}{l}\text { Grade } \\
\text { Poorly Diff. }\end{array}$ & $1.56(1.16-2.10)$ & $<0.0001$ & $1.38(0.97-1.94)$ & 0.0667 \\
\hline LVI & $0.46(0.33-0.63)$ & $<0.0001$ & $0.47(0.34-0.66)$ & $<0.0001$ \\
\hline TNBC & $1.82(1.24-2.59)$ & 0.0027 & $1.39(0.89-2.11)$ & 0.1379 \\
\hline PARP (High expression) & $1.69(1.26-2.29)$ & 0.0005 & $1.43(1.01-2.04)$ & 0.0428 \\
\hline
\end{tabular}

mitochondrial apoptotic pathway in $\mathrm{BC}$ cells. $\mathrm{BC}$ cells were treated with olaparib and embelin either alone or combination for 48 hours. Following treatment, cells were stained with $\mathrm{JC} 1$ dye for detection of loss of mitochondrial membrane potential by flow cytometry. As shown in Figure 4B, co-treatment of olaparib and embelin caused loss of mitochondrial membrane potential as measured by JC1 stained green florescence depicting apoptotic cells
A
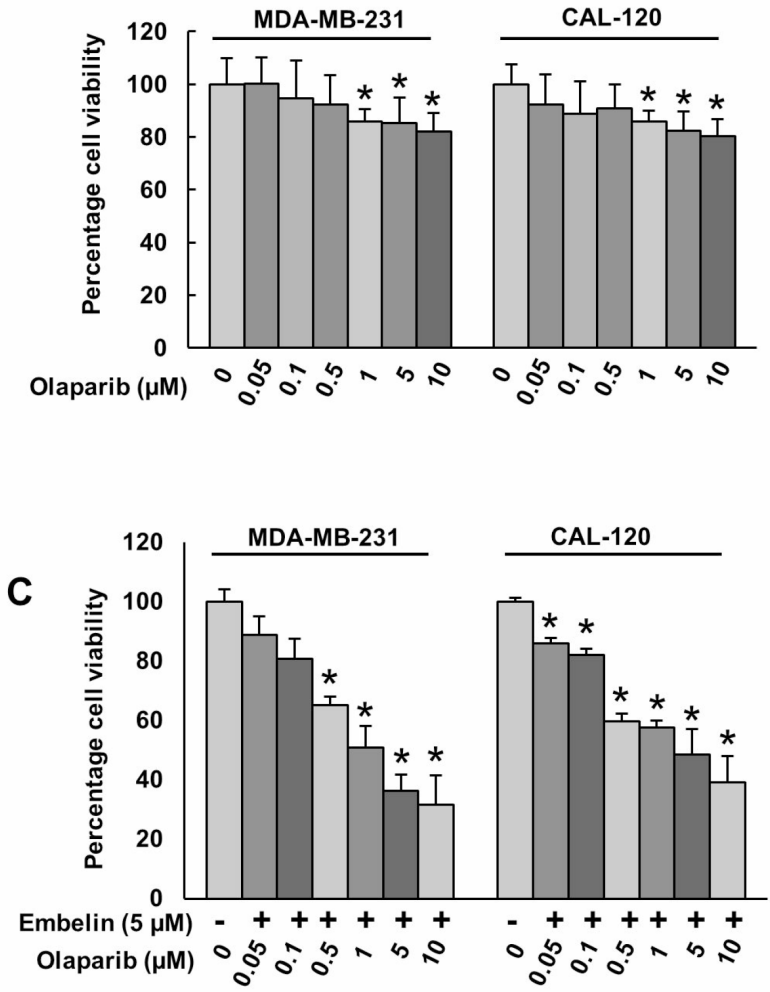

B

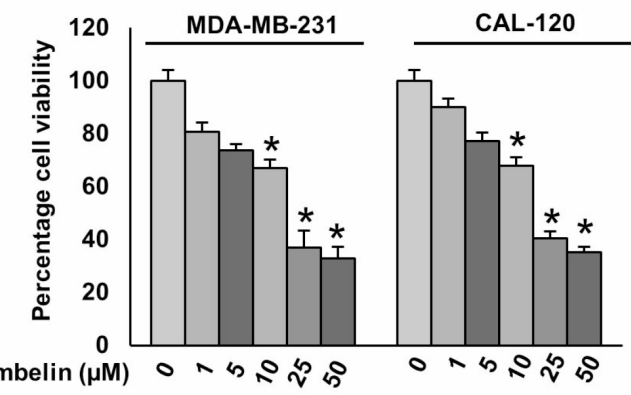

D

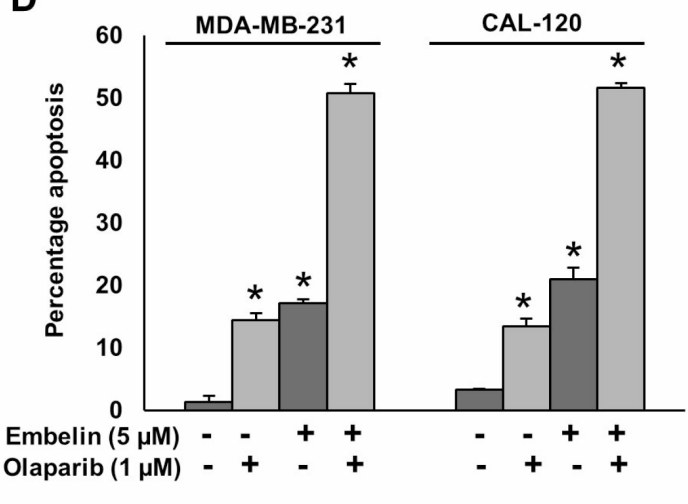

Figure 2: Olaparib and embelin induces synergistic apoptotic response in BC cells. (A) Effect of olaparib on BC cell viability. BC cells were incubated with indicated doses of olaparib for 48 hours. Cell viability was performed using MTT. (B) Effect of embelin on $\mathrm{BC}$ cell viability. $\mathrm{BC}$ cells were incubated with indicated doses of embelin for 48 hours. Cell viability was performed using MTT. (C) Synergistic effect of olaparib and embelin on BC cell viability. BC cells were incubated with indicated doses of olaparib and embelin either alone or combination for 48 hours. Cell viability was performed using MTT. (D) Synergistic effect of olaparib and embelin on inducing apoptosis in $\mathrm{BC}$ cells. $\mathrm{BC}$ cells were incubated with indicated doses of olaparib and embelin either alone or combination for 48 hours and cells were stained with flourescein-conjugated annexin- $\mathrm{V}$ and propidium iodide (PI) and analyzed by flow cytometry. Data presented in the bar graphs are the mean \pm SD of three independent experiments. "Indicates a statistically significant difference compared with control with $p<0.05$. 
in both cell lines tested leading to release of cytochrome c from mitochondria into cytosol (Figure 4C). These results suggest that olaparib activates caspase- 8 mediated extrinsic pathway whereas embelin induces intrinsic apoptotic signaling pathway in BC cells.

\section{Olaparib and embelin synergistically inhibits MDA-MB-231 xenograft growth in vivo}

Combination of olaparib and embelin induced synergistic apoptotic response in vitro. Therefore, we sought to determine whether this combination of treatment will result in anti-cancer effect in vivo. For xenograft

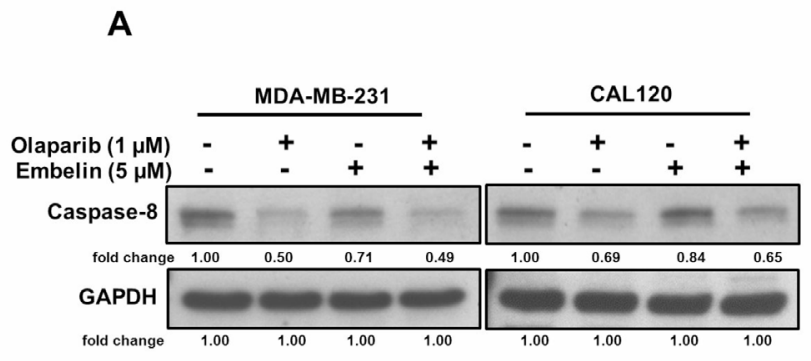

C

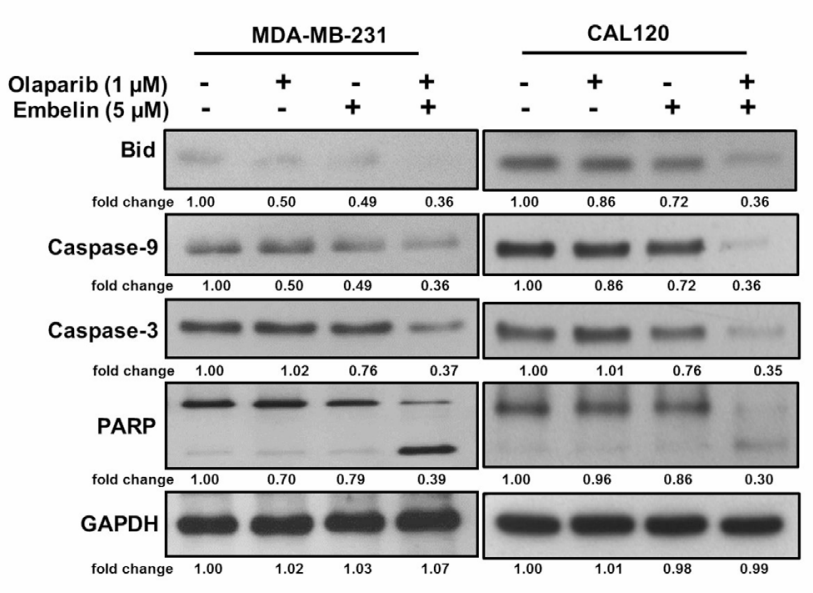

study, MDA-MB-231 cells $\left(4 \times 10^{6}\right.$ cells per mouse) were subcutaneously injected into the flanks of nude mice. After 1 week of inoculation, mice were randomly assigned into four groups: The first group received $0.9 \%$ normal saline as vehicle control while the other three groups received olaparib (10 mg/kg), embelin $(5 \mathrm{mg} / \mathrm{kg})$ and combination of both, injected twice weekly, intra-peritoneally. After 4 weeks' treatment, mice were sacrificed and tumors were collected. There was no significant change in the tumor volume after treatment with olaparib and embelin alone but combination of both the drugs reduced the tumor volume within 3 weeks of treatment and reached significance at the end of the fourth week (Figure 5A). The
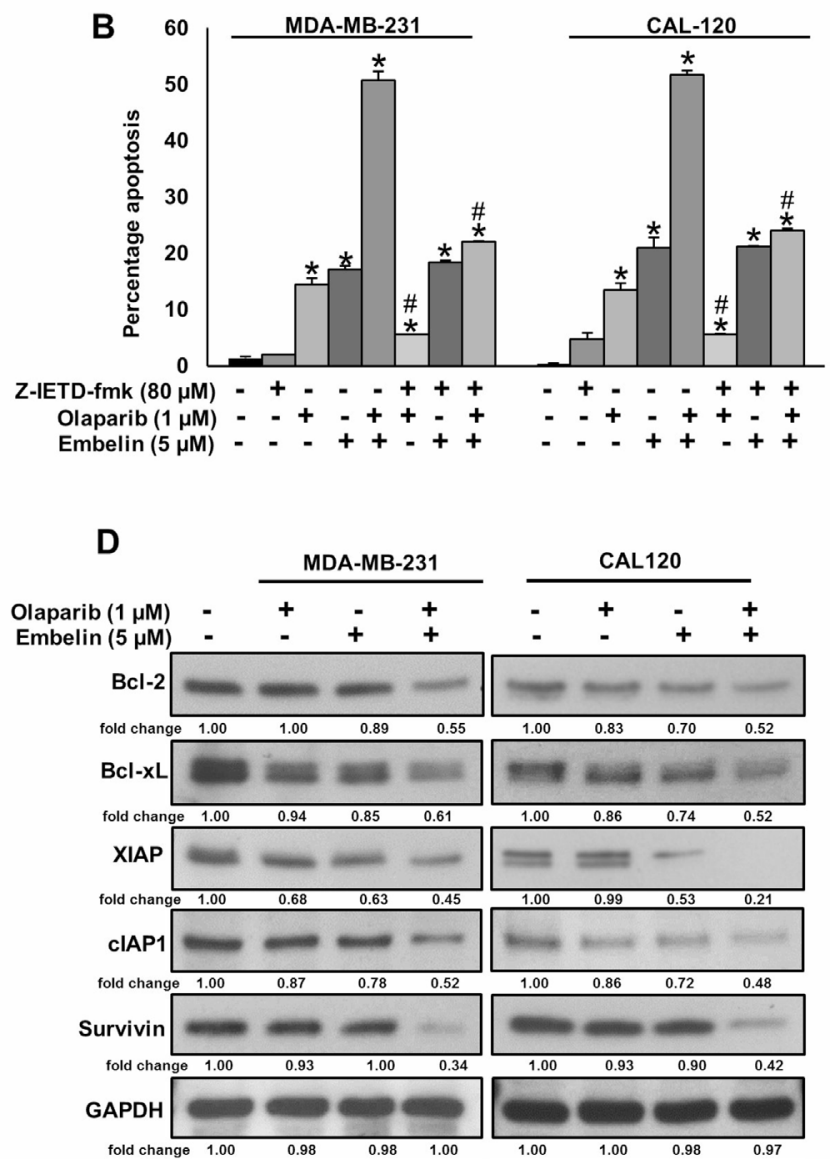

Figure 3: Olaparib but not embelin activates caspase-8 mediated extrinsic apoptotic signaling pathway in BC cells. (A) Effect of olaparib and embelin on cleavage of caspase-8 in BC cells. BC cells were incubated with indicated doses of olaparib and embelin either alone or combination for 48 hours. After cell lysis, equal amounts of proteins were separated by SDS-PAGE, transferred to immobilon membrane, and immuno-blotted with antibodies against caspase- 8 and GAPDH as indicated. (B) Effect of caspase-8 inhibition on olaparib and embelin induced apoptosis in BC cells. BC cells were pre-treated with caspase- 8 inhibitor, z-IETD-fmk for 3 hours and subsequently treated with olaparib and embelin either alone or combination for 48 hours and cells were stained with flourescein-conjugated annexin-V and propidium iodide (PI) and analyzed by flow cytometry. Data presented in bar graphs are the mean $\pm \mathrm{SD}$ of three independent experiments. *and \# indicate statistically significant differences compared to control without treatment or olaparib/embelin/combination treatment, respectively with $p<0.05$. (C) Effect of olaparib and embelin on truncation of Bid and activation of caspase cascade in BC cells. $\mathrm{BC}$ cells were incubated with indicated doses of olaparib and embelin either alone or combination for 48 hours. Thereafter, the cells were lysed and proteins were immunoblotted with antibodies against Bid, Caspase-9, Caspase-3, PARP and GAPDH. (D) Effect of olaparib and embelin on the inhibition of anti-apoptotic proteins expression in BC cells. BC cells were incubated with indicated doses of olaparib and embelin either alone or combination. After 48 hours, cells were lysed and proteins were immunoblotted with antibodies against Bcl-2, Bclxl, XIAP, cIAP1, Survivin and GAPDH. 
weight of the tumor also reduced significantly following co-treatment of olaparib and embelin as compared to independent treatments (Figure 5B). Images of tumor showed that co-treatment of olaparib and embelin caused shrinkage of tumor size (Figure 5C). Finally, proteins isolated from tumors showed down-regulation of XIAP as well as cleavage of caspase-9, caspase-3 and PARP following co-treatment with olaparib and embelin indicating that co-targeting PARP and XIAP can regress $\mathrm{BC}$ xenografts in nude mice (Figure 5D).

\section{DISCUSSION}

PARP mediates DNA single and double strand break repair through BER pathway [35-37]. Over-expression of PARP has been noted in several cancers, including breast cancer [9, 38-43]. To our knowledge, this is the first report on PARP protein expression in a large cohort of primary Middle Eastern BC by immunohistochemistry in a tissue microarray format. We show that high nuclear PARP (nPARP) expression was detectable in $44.7 \%$ of the examined cases. nPARP expression was, in general, correlated with more aggressive tumor characteristics. The aggressive TNBC cases showed the highest frequency of nPARP. Furthermore, high nPARP expression was significantly associated with poor overall survival even in multi-variate analysis. Our findings are similar to a study by Rojo et al., who showed a poor overall survival in early breast cancer cases with over-expression of nPARP [9]. Donizy et al. also reported that over-expression of PARP was an unfavorable prognostic marker [44]. The patient poor survival in our cohort worsened significantly if the tumors co-expressed both PARP and XIAP, which could suggest that these two genetic deregulations might synergistically affect the survival outcome of breast cancer in this ethnicity.

Several cancers like TNBCs and ovarian cancers with mutant BRCA1 exhibit sensitivity to PARP inhibitors [45-49]. On the basis of our clinico-pathological observations, we hypothesized that co-targeting of both PARP and XIAP might be an affective therapeutic target in treating aggressive $\mathrm{BC}$ and might extend the utility of olaparib beyond $B R C A$ mutant breast cancer patients. In the present work, we explored if PARP inhibitors might be extended beyond $B R C A$-deficient $\mathrm{BC}$. We provide
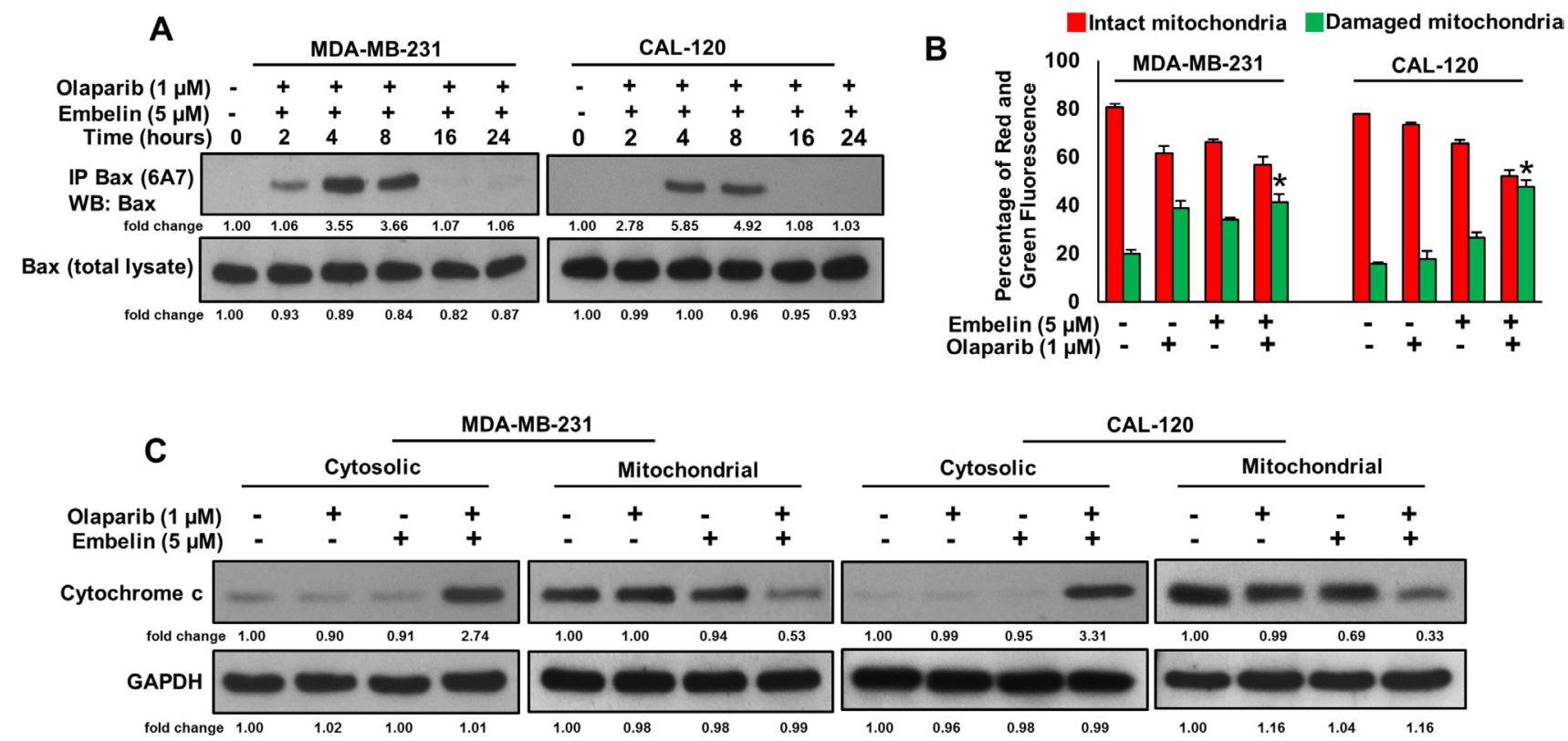

Figure 4: Olaparib and embelin synergistically induces mitochondrial apoptotic pathway in BC cells. (A) Effect of olaparib and embelin on Bax activation in BC cells. BC cells were cotreated with olaparib and embelin for indicated time periods. Following treatment, cells were lysed in 1\% Chaps lysis buffer and subjected to immuno-precipitation with anti-Bax 6A7 monoclonal antibody and probed with specific polyclonal anti-Bax antibody (top band) for detection of conformationally changed Bax protein. In addition, the total cell lysates (bottom band) were applied directly to SDS-PAGE, transferred to immobilon membrane and immunoblotted with specific anti-Bax polyclonal antibody. (B) Effect of olaparib and embelin on mitochondrial membrane potential. BC cells were treated with and without indicated doses olaparib and embelin either alone or combination for 48 hours. Cells with intact mitochondrial membrane potential (red bar) and with lost mitochondrial membrane potential (green bar) was measured by JC-1 staining and analyzed by flow cytometry as described in Materials and Methods. Data presented in bar graphs are the mean \pm SD of three independent experiments. *indicate statistically significant differences compared to control without treatment with $p<0.05$. (C) Effect of olaparib and embelin on cytochrome-c release. BC cells were treated with olaparib and embelin either alone or combination for 48 hours. Mitochondrial free cytoplasmic as well as mitochondrial fractions were isolated as described in Materials and Methods. Cell extracts were separated on SDSPAGE, transferred to PVDF membrane, and immuno-blotted with an antibody against cytochrome c and GAPDH. 
evidence that PARP inhibition leads to decreased cell viability through apoptosis in $B R C A$ proficient $\mathrm{BC}$ cells. To gain more insight into the molecular mechanisms involved in decreasing viability following treatment, we investigated several representative apoptosis markers and found that PARP inhibition causes apoptosis through induction of caspase 8 . The finding that caspase 8 inhibition significantly inhibited olaparib induced apoptosis further supports the notion that PARP inhibition could induce extrinsic apoptotic signaling pathway in BC cells.

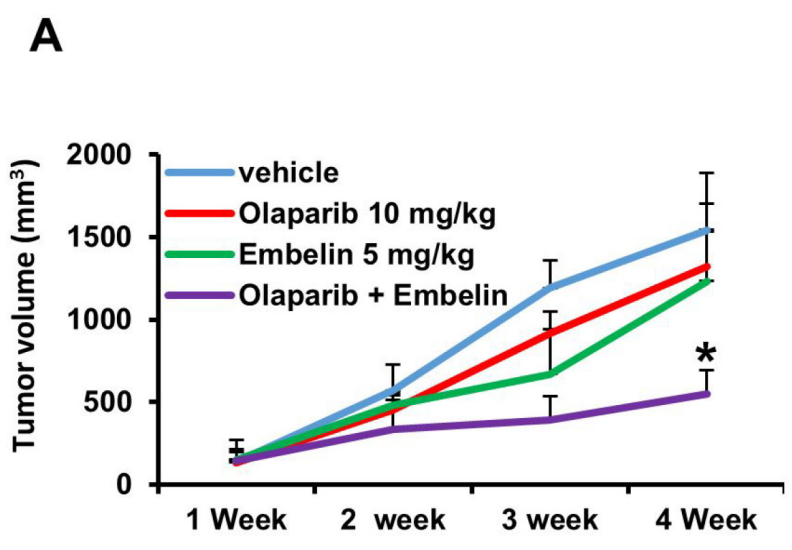

C

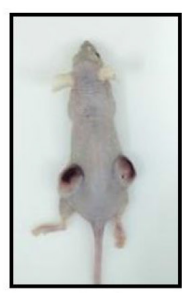

Vehicle

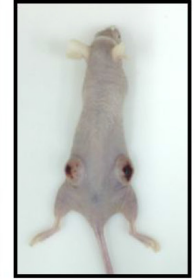

Olaparib $10 \mathrm{mg} / \mathrm{kg}$

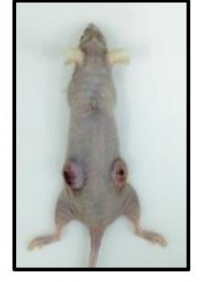

Embelin $5 \mathrm{mg} / \mathrm{kg}$

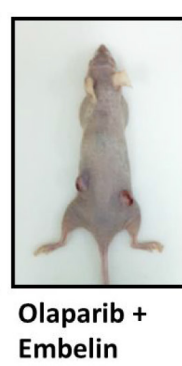

Embelin

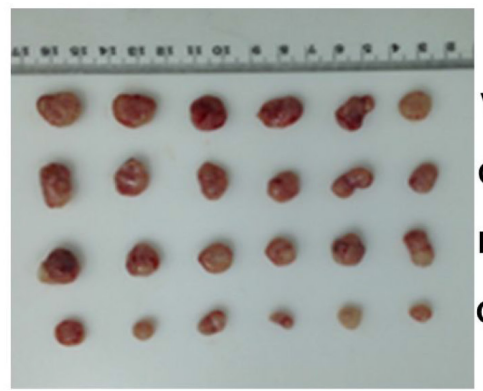

Vehicle

Olaparib $10 \mathrm{mg} / \mathrm{kg}$

Embelin 5 mg/kg

Olaparib + Embelin
Since we have previously demonstrated the effect of XIAP inhibition on BC cells [21] and the fact that our clinical samples showed that XIAP overexpression does significantly worsen the overall survival of patients who are overexpressing PARP protein, we sought to examine the effect of combining olaparib and embelin on BC cell viability and apoptosis. We observed that the cytotoxic effect of PARP and XIAP inhibition, administered in a sequential combination regimen was superior to PARP inhibition alone in downregulating survival and inducing apoptosis in $B R C A$ proficient
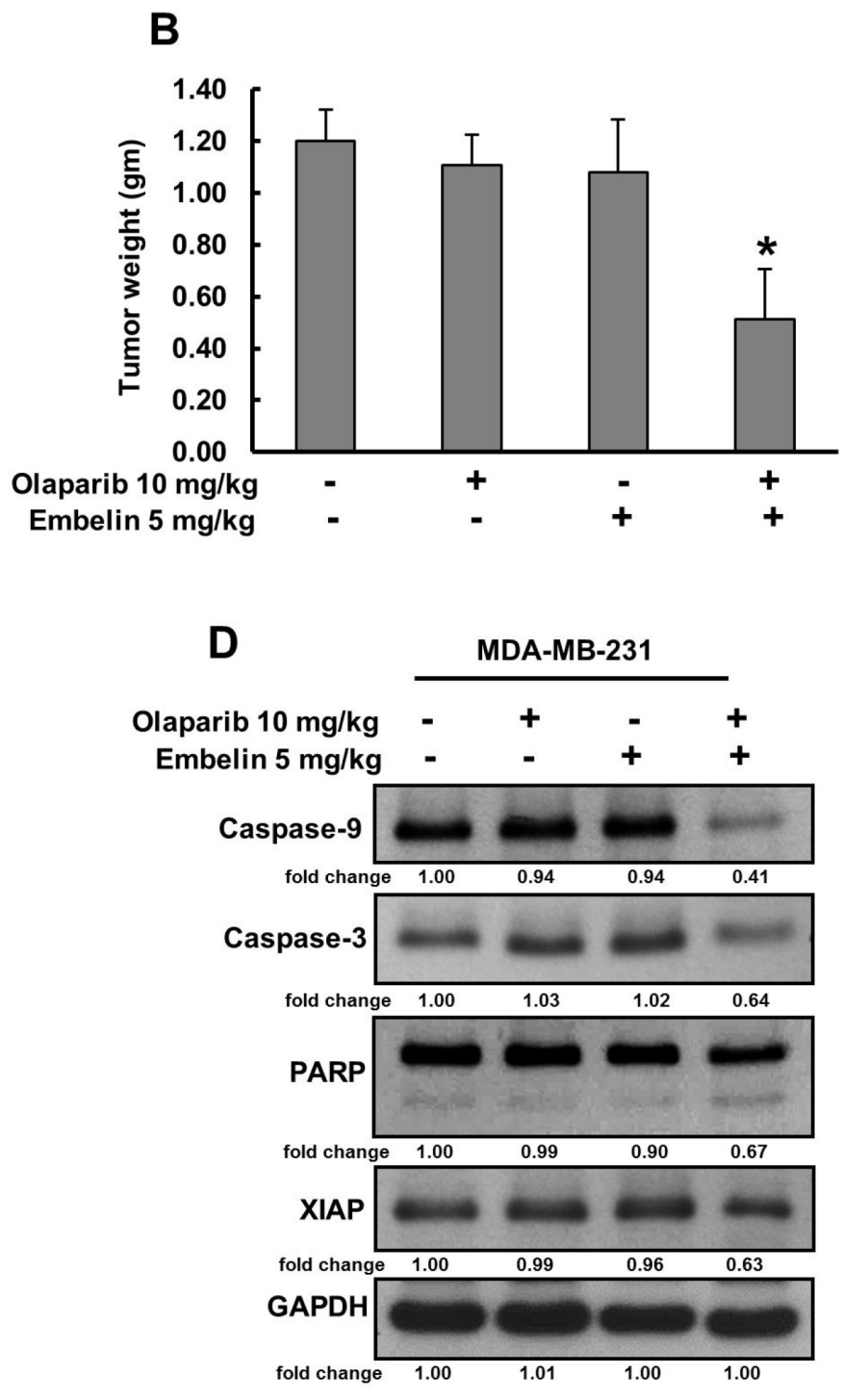

Figure 5: Olaparib and embelin synergistically inhibits the growth of MDA-MB-231 xenografts. Female nude mice 6 weeks of age were injected subcutaneously with $4 \times 10^{6}$ MDA-MB-231 cells. After one week, mice were treated intraperitoneal with olaparib (10 mg/kg), embelin (5 mg/kg) and combination twice a week for 30 days. DMSO (5\%) in PBS served as a vehicle control. (A) Volume of each tumor was measured every week and the average $(n=5)$ tumor volume of mice was calculated, ${ }^{*} p<0.05$ inhibition of BC tumor growth by combination of olaparib and embelin treatment. (B) After 4 weeks of treatment, mice were sacrificed and tumor weights were measured, " $p<0.05$ compared to vehicle-treated mice by Student's $t$-test. (C) Representative tumor images of vehicle, olaparib, embelin and combination of olaparib and embelin treated mice. (D) Whole cell lysate from mice treated with vehicle, olaparib, embelin and combination of olaparib and embelin were isolated and $10 \mu \mathrm{g}$ protein were separated by SDS-PAGE, transferred to PVDF membrane, and immunoblotted with antibodies against Caspase-9, Caspase-3, PARP, XIAP and GAPDH. 
BC cell lines. Interestingly, the combination treatment of olaparib and embelin significantly reduced tumor growth in vivo when compared to treatment with each agent alone.

In summary, our result showed that PARP overexpression is a poor prognostic marker in Middle Eastern BC. In vitro data suggests that XIAP inhibition by natural compound, embelin, improved the response to PARP inhibition by olaparib and serves as a guide to translate this to substantial anti-tumor activity in vivo. The data improves our understanding of the roles that PARP and XIAP play, as well as support the clinical development of combined inhibition. This combined targeted approach might expand the role of PARP inhibition therapy beyond $B R C A$-deficient $\mathrm{BC}$ in the future.

\section{MATERIALS AND METHODS}

\section{Patient samples and data collection}

One thousand and eight patients with $\mathrm{BC}$ diagnosed between 1990 and 2011 were selected from the files of the King Faisal Specialist Hospital and Research Centre (KFSHRC). The patients included in this study had their diagnosis, treatment and follow-up care in the Department of Surgical Oncology at KFSHRC. The histologic subtype of each breast tumor sample was determined according to World Health Organization (WHO) criteria. Detailed clinico-pathological data, including follow-up data, were noted from case records and summarized in Table 3. Waiver of consent was obtained for the study from the Institutional Review Board (IRB) and Research Ethics Committee (REC) of KFSHRC under Project RAC number 2170021 on BC archival clinical samples. All samples were analyzed in a tissue microarray (TMA) format.

\section{Tissue microarray (TMA) construction}

TMA construction was performed as described earlier [50]. Briefly, tissue cylinders with a diameter of 0.6 $\mathrm{mm}$ were punched from representative tumor regions of each donor tissue block and brought into recipient paraffin block using a modified semiautomatic robotic precision instrument (Beecher Instruments, Woodland, WI). Two cores of $\mathrm{BC}$ were arrayed from each case.

\section{Immunohistochemistry (IHC) staining and evaluation}

Standard protocol was followed for IHC staining. For antigen retrieval, Dako (Dako Denmark A/S, Glostrup, Denmark) Target Retrieval Solution pH 9.0 (Catalog number S2368) was used, and the slides were placed in Pascal pressure cooker at $120^{\circ} \mathrm{C}$ for 10 minutes. The primary antibodies used for staining tissue microarray sections and their dilutions are listed in Supplementary Table 1. The Dako Envision Plus System kit was used as the secondary detection system with 3, 30-diaminobenzidine as chromogen. All slides were counterstained with haematoxylin, dehydrated, cleared and mounted. Negative controls included omission of the primary antibody. Normal tissues of different organ system were also included in the TMA to serve as control. Only fresh cut slides were stained simultaneously to minimize the influence of slide aging and maximise reproducibility of the experiment.

PARP scoring was done as described previously using the quickscore (QS) method [38]. Briefly, the proportion of positive cells was scored on a scale from 1 to $6(1=1-4 \% ; 2=5-19 \% ; 3=20-39 \% ; 4=40-59 \%$; $5=60-79 \%$; and $6=80-100 \%)$. The intensity of the positively staining cells was given a score from 0 to $3(0$ = no staining; $1=$ weak, $2=$ intermediate, and $3=$ strong staining). QS was calculated by multiplying the percentage score by the intensity score, to yield a final score ranging from 0-18. Based on the QS, nuclear PARP-1 expression was graded as low (0-9) or high (10-18). Other IHC markers such as XIAP and Ki67 were scored as described previously $[22,51,52]$.

\section{Cell culture}

BC cell lines, CAL-120 and MDA-MB-231 were purchased from American Type Culture Collection (ATCC) and grown in RPMI 1640 media supplemented with 10\% fetal bovine serum (FBS), 100 Units/ml penicillin/streptomycin and $100 \mathrm{Units} / \mathrm{ml}$ glutamine. Cells were cultured at $37^{\circ} \mathrm{C}$ under a humidified 95\%: 5\% (v/v) mixture of air and $\mathrm{CO}_{2}$. Both cell lines were authenticated in house using short tandem repeats PCR and the results (Supplementary Table 2) were in concordance with published data $[53,54]$. All experiments were performed using 5\% FBS in RPMI 1640 media.

\section{Reagents and antibodies}

Olaparib was purchased from Selleck Chemicals (Houston, TX). Embelin was purchased from Tocris Bioscience (Ellisville, MO). Antibodies against PARP, caspase-8, caspase-9, caspase-3, Bcl-2, Bcl-xl and cIAP1 were purchased from Cell Signaling Technologies (Beverly, MA). XIAP antibody was purchased from BD Pharmingen (San Diego, CA, USA). Survivin, Cytochrome $\mathrm{c}$ and GAPDH antibodies were purchased from Santa Cruz Biotechnology, Inc. (Santa Cruz, CA). Annexin V was purchased from Thermo Fischer Scientific (Waltham, MA). Caspase-8 inhibitor, z-IETD-FMK was purchased from R\&D Systems (Minneapolis, MN, USA).

\section{Cell viability assay}

$10^{4}$ cells were incubated in triplicate in a 96-well plate in the presence or absence of indicated test doses 
Table 3: Clinico-pathological variables for the patient cohort $(n=1008)$

\begin{tabular}{|c|c|}
\hline Age & $n(\%)$ \\
\hline Young age $(\leq 50)$ & $686(68.1)$ \\
\hline Old age $(>50)$ & $322(31.9)$ \\
\hline Median (in years) & 45.0 \\
\hline Range $(\mathrm{IQR})^{\wedge}$ & $39.0-54.0$ \\
\hline \multicolumn{2}{|l|}{ Histological type } \\
\hline Infiltrating Ductal carcinoma & $917(90.9)$ \\
\hline Infiltrating Lobular carcinoma & $46(4.6)$ \\
\hline Mucinous carcinoma & $16(1.6)$ \\
\hline Others & $29(2.9)$ \\
\hline \multicolumn{2}{|l|}{ TNM Stage } \\
\hline I & $87(8.6)$ \\
\hline II & $407(40.4)$ \\
\hline III & $381(37.8)$ \\
\hline IV & $91(9.0)$ \\
\hline Unknown & $42(4.2)$ \\
\hline \multicolumn{2}{|l|}{ Histologic Grade } \\
\hline Well differentiated & $81(8.0)$ \\
\hline Moderately differentiated & $511(50.7)$ \\
\hline Poorly differentiated & $405(40.2)$ \\
\hline Unknown & $11(1.1)$ \\
\hline \multicolumn{2}{|l|}{ Triple Negative Breast Cancer } \\
\hline Yes & $149(14.8)$ \\
\hline No & $851(84.4)$ \\
\hline Unknown & $8(0.8)$ \\
\hline \multicolumn{2}{|l|}{ Survival Duration (in months) } \\
\hline Median & 48.0 \\
\hline Range $(\mathrm{IQR})^{\wedge}$ & $26.0-74.0$ \\
\hline
\end{tabular}

of olaparib and embelin either alone or combination in a final volume of $0.20 \mathrm{ml}$ for 48 hours. Cell viability was determined by MTT assay, as described earlier [55]. Replicates of 6 wells for each dosage including vehicle control were analyzed for each experiment.

\section{Annexin V staining}

$\mathrm{BC}$ cells were treated with olaparib and embelin either alone or combination for 48 hours and then were harvested. The percentage apoptosis was measured by flow cytometry after staining with fluorescein-conjugated annexin- $\mathrm{V}$ and propidium iodide (PI) as described earlier [21].

\section{Cell lysis and immunoblotting}

Following treatment, BC cells were lysed in phosphorylation lysis buffer containing $50 \mathrm{mM}$ Hepes $(\mathrm{pH}$ 7.3), $150 \mathrm{mM} \mathrm{NaCl}, 1.5 \mathrm{mM} \mathrm{MgCl}_{2}, 1.0 \mathrm{mM}$ EDTA (pH 8.0), $100 \mathrm{mM} \mathrm{NaF}, 10 \mathrm{mM} \mathrm{Na}_{2} \mathrm{H}_{2} \mathrm{P}_{2} \mathrm{O}_{7}, 200 \mu \mathrm{M} \mathrm{Na}_{3} \mathrm{VO}_{4}$ and 1X proteasome inhibitors (Roche pharmaceuticals, Basel, Switzerland). Following lysis, cells were spun at $14,000 \mathrm{rpm}$ for 15 minutes at $4^{\circ} \mathrm{C}$ and protein amounts were measured using Bradford assay (Life Technologies). Equal amounts of protein were separated on SDS-Page and immunoblotted with different antibodies as described previously [56].

\section{Detection of Bax conformational changes}

Detection of Bax conformation was performed as previously described [57]. In brief, cells were cotreated with olaparib and embelin for different time periods after which cells were harvested and washed with PBS and lysed with Chaps lysis buffer (10 mM HEPES (pH 7.4), $150 \mathrm{mM} \mathrm{NaCl}, 1 \%$ Chaps) containing protease inhibitors. Concentration of proteins was assessed by Bradford assay and $200 \mu \mathrm{g}$ of total protein was incubated with $6 \mu \mathrm{g}$ of anti-Bax 6A7 monoclonal antibody for 2 hours at $4^{\circ} \mathrm{C}$. Following incubation, $25 \mu \mathrm{l}$ of protein G-beads were 
added into the reaction and incubated at $4^{\circ} \mathrm{C}$ overnight on a shaker with gentle agitation. Following 4 washes in Chaps lysis buffer, samples were separated by SDS-PAGE, transferred and immunoblotted using N20 Bax polyclonal antibody (Santa Cruz, CA).

\section{Measurement of mitochondrial membrane potential and cytochrome c release}

Following treatment with olaparib and embelin for 48 hours, BC cells were harvested and stained with JC1 dye (Thermo Fischer Scientific, Waltham, MA) for 30 minutes at $37^{\circ} \mathrm{C}$ and analyzed by flow cytometry. In the same experiment, cells were also fractionized into mitochondrial free cytosolic and cytosolic free mitochondrial fractions and separated on SDS-Page for immunoblotting as described previously $[58,59]$.

\section{Animals and xenografts study}

Six-week-old female nude mice were obtained from Jackson Laboratories (Bar Harbor, ME) and maintained in a pathogen-free animal facility at least 1 week before use. All animal studies were performed in accordance with institutional guidelines. For xenograft study, MDAMB-231 cells $\left(4 \times 10^{6}\right.$ cells per mouse $)$ were re-suspended in serum-free medium with matrigel basement membrane matrix (BD Biosciences) at a 1:1 ratio (total volume $=100$ $\mu \mathrm{l})$ and subcutaneously injected into the flanks of nude mice. After tumors grew to about $100 \mathrm{~mm}^{3}$, mice were treated intraperitoneally with olaparib $(10 \mathrm{mg} / \mathrm{kg})$, embelin $(5 \mathrm{mg} / \mathrm{kg}$ ) and combination twice a week for 30 days. The body weight and tumor volume of each mouse was monitored weekly [55]. After 4 weeks' treatment, mice were sacrificed and individual tumors were weighed, then snap-frozen in liquid nitrogen for storage.

\section{Statistical analysis}

Contingency table analysis and chi-square tests were used to study the relationship between clinico-pathological variables and PARP expression. Overall Survival curves were generated using the Kaplan-Meier method, with significance evaluated using the Mantel-Cox log-rank test. The limit of significance for all analyses was defined as $p$ value of $<0.05$; two-sided tests were used in these calculations. The JMP10.0 (SAS Institute, Inc., Cary, NC) software package was used for data analyses.

For all functional studies, data presented are means \pm SD of triplicates in an independent experiment, which was repeated for at least two times with the same results. For multiple comparisons, one-way analysis of variance (ANOVA) was performed using IBM SPSS Statistics 21 software (IBM Corp., Armonk, NY). Values of $p<0.05$ were considered statistically significant.

\section{Author contributions}

AKS and PP: Designed, performed experiments and wrote the manuscript, SPD: Performed experiments, FA, AT and DA: Collected and analyzed all the clinical samples and data, SKP: Prepared the TMA and conducted all the immunohistochemistry experiments and scoring of IHC spots, KSA: Made substantial contributions to conception, design and acquisition of data along with analysis and interpretation of data; Prepared and wrote the manuscript. KSA gave the final approval for the submission of the manuscript. This is to confirm that all authors read and approved the final manuscript.

\section{ACKNOWLEDGMENTS AND FUNDING}

We would like to acknowledge Dr. Maqbool Ahmed, Saravanan Thangavel, Rafia Begum, Roxanne Melosantos, Valorie M Balde and Padmanaban Annaiyappanaidu for their technical assistance and Zeeshan Qadri for statistical analysis. This study was not supported by any funding agency therefore the authors declare that there is no funding information to be disclosed for this manuscript.

\section{CONFLICTS OF INTEREST}

There are no conflicts of interest to report.

\section{REFERENCES}

1. Bazarbashi S, Al Eid H, Minguet J. Cancer Incidence in Saudi Arabia: 2012 Data from the Saudi Cancer Registry. Asian Pac J Cancer Prev. 2017; 18:2437-44. https://doi. org/10.22034/APJCP.2017.18.9.2437.

2. Dai X, Li Y, Bai Z, Tang XQ. Molecular portraits revealing the heterogeneity of breast tumor subtypes defined using immunohistochemistry markers. Sci Rep. 2015; 5:14499. https://doi.org/10.1038/srep14499.

3. Kim C, Gao R, Sei E, Brandt R, Hartman J, Hatschek T, Crosetto N, Foukakis T, Navin NE. Chemoresistance Evolution in Triple-Negative Breast Cancer Delineated by Single-Cell Sequencing. Cell. 2018; 173:879-93.e13. https://doi.org/10.1016/j.cell.2018.03.041.

4. Qiu J, Xue X, Hu C, Xu H, Kou D, Li R, Li M. Comparison of clinicopathological features and prognosis in triplenegative and non-triple negative breast cancer. J Cancer. 2016; 7:167-73. https://doi.org/10.7150/jca.10944.

5. Rouleau M, Patel A, Hendzel MJ, Kaufmann SH, Poirier GG. PARP inhibition: PARP1 and beyond. Nat Rev Cancer. 2010; 10:293-301. https://doi.org/10.1038/nrc2812.

6. Schreiber V, Dantzer F, Ame JC, de Murcia G. Poly(ADPribose): novel functions for an old molecule. Nat Rev 
Mol Cell Biol. 2006; 7:517-28. https://doi.org/10.1038/ nrm1963.

7. D'Amours D, Desnoyers S, D'Silva I, Poirier GG. Poly(ADP-ribosyl)ation reactions in the regulation of nuclear functions. Biochem J. 1999; 342:249-68. https:// doi.org/10.1042/bj3420249.

8. Hassa PO, Hottiger MO. The diverse biological roles of mammalian PARPS, a small but powerful family of polyADP-ribose polymerases. Front Biosci. 2008; 13:3046-82. https://doi.org/10.2741/2909.

9. Rojo F, García-Parra J, Zazo S, Tusquets I, Ferrer-Lozano J, Menendez S, Eroles P, Chamizo C, Servitja S, RamírezMerino N, Lobo F, Bellosillo B, Corominas JM, et al. Nuclear PARP-1 protein overexpression is associated with poor overall survival in early breast cancer. Ann Oncol. 2012; 23:1156-64. https://doi.org/10.1093/annonc/mdr361.

10. Ghabreau L, Roux JP, Frappart PO, Mathevet P, Patricot LM, Mokni M, Korbi S, Wang ZQ, Tong WM, Frappart L. Poly(ADP-ribose) polymerase-1, a novel partner of progesterone receptors in endometrial cancer and its precursors. Int J Cancer. 2004; 109:317-21. https://doi. org/10.1002/ijc.11731.

11. Soldatenkov VA, Albor A, Patel BK, Dreszer R, Dritschilo A, Notario V. Regulation of the human poly(ADP-ribose) polymerase promoter by the ETS transcription factor. Oncogene. 1999; 18:3954-62. https://doi.org/10.1038/ sj.onc. 1202778 .

12. Tomoda T, Kurashige T, Moriki T, Yamamoto H, Fujimoto $\mathrm{S}$, Taniguchi T. Enhanced expression of poly(ADP-ribose) synthetase gene in malignant lymphoma. Am J Hematol. 1991; 37:223-27. https://doi.org/10.1002/ajh.2830370402.

13. Shimizu S, Nomura F, Tomonaga T, Sunaga M, Noda M, Ebara M, Saisho H. Expression of poly(ADP-ribose) polymerase in human hepatocellular carcinoma and analysis of biopsy specimens obtained under sonographic guidance. Oncol Rep. 2004; 12:821-25. https://doi.org/10.3892/ or.12.4.821.

14. Bièche I, de Murcia G, Lidereau R. Poly(ADP-ribose) polymerase gene expression status and genomic instability in human breast cancer. Clin Cancer Res. 1996; 2:1163-67.

15. Dziadkowiec KN, Gąsiorowska E, Nowak-Markwitz E, Jankowska A. PARP inhibitors: review of mechanisms of action and BRCA1/2 mutation targeting. Prz Menopauzalny. 2016; 15:215-219. https://doi.org/10.5114/pm.2016.65667.

16. Lord CJ, Ashworth A. The DNA damage response and cancer therapy. Nature. 2012; 481:287-94. https://doi. org/10.1038/nature10760.

17. Bryant HE, Schultz N, Thomas HD, Parker KM, Flower D, Lopez E, Kyle S, Meuth M, Curtin NJ, Helleday T. Specific killing of BRCA2-deficient tumours with inhibitors of poly(ADP-ribose) polymerase. Nature. 2005; 434:913-17. https://doi.org/10.1038/nature03443. Erratum in: Nature. 2007 May 17;447(7142):346.

18. Farmer H, McCabe N, Lord CJ, Tutt AN, Johnson DA, Richardson TB, Santarosa M, Dillon KJ, Hickson I,
Knights C, Martin NM, Jackson SP, Smith GC, Ashworth A. Targeting the DNA repair defect in BRCA mutant cells as a therapeutic strategy. Nature. 2005; 434:917-21. https:// doi.org/10.1038/nature03445.

19. Wooster R, Weber BL. Breast and ovarian cancer. N Engl J Med. 2003; 348:2339-47. https://doi.org/10.1056/ NEJMra012284.

20. Gucalp A, Traina TA. Triple-negative breast cancer: adjuvant therapeutic options. Chemother Res Pract. 2011; 2011:696208. https://doi.org/10.1155/2011/696208.

21. Hussain AR, Siraj AK, Ahmed M, Bu R, Pratheeshkumar P, Alrashed AM, Qadri Z, Ajarim D, Al-Dayel F, Beg S, Al-Kuraya KS. XIAP over-expression is an independent poor prognostic marker in Middle Eastern breast cancer and can be targeted to induce efficient apoptosis. BMC Cancer. 2017; 17:640. https://doi.org/10.1186/s12885-017-3627-4.

22. Hussain AR, Bu R, Ahmed M, Jehan Z, Beg S, Al-Sobhi S, Al-Dayel F, Siraj AK, Uddin S, Al-Kuraya KS. Role of X-linked inhibitor of apoptosis as a prognostic marker and therapeutic target in papillary thyroid carcinoma. $\mathrm{J}$ Clin Endocrinol Metab. 2015; 100:E974-85. https://doi. org/10.1210/jc.2014-4356.

23. Hussain AR, Uddin $\mathrm{S}$, Ahmed $\mathrm{M}, \mathrm{Bu} \mathrm{R}$, Ahmed SO, Abubaker J, Sultana M, Ajarim D, Al-Dayel F, Bavi PP, Al-Kuraya KS. Prognostic significance of XIAP expression in DLBCL and effect of its inhibition on AKT signalling. J Pathol. 2010; 222:180-90. https://doi.org/10.1002/ path.2747.

24. Deveraux QL, Reed JC. IAP family proteins - suppressors of apoptosis. Genes Dev. 1999; 13:239-52. https://doi. org/10.1101/gad.13.3.239.

25. Liu Z, Sun C, Olejniczak ET, Meadows RP, Betz SF, Oost T, Herrmann J, Wu JC, Fesik SW. Structural basis for binding of Smac/DIABLO to the XIAP BIR3 domain. Nature. 2000; 408:1004-08. https://doi.org/10.1038/35050006.

26. Riedl SJ, Renatus M, Schwarzenbacher R, Zhou Q, Sun C, Fesik SW, Liddington RC, Salvesen GS. Structural basis for the inhibition of caspase- 3 by XIAP. Cell. 2001; 104:791800. https://doi.org/10.1016/S0092-8674(01)00274-4.

27. Pulliam N, Fang F, Ozes AR, Tang J, Adewuyi A, Keer H, Lyons J, Baylin SB, Matei D, Nakshatri H, Rassool FV, Miller KD, Nephew KP. An Effective Epigenetic-PARP Inhibitor Combination Therapy for Breast and Ovarian Cancers Independent of BRCA Mutations. Clin Cancer Res. 2018; 24:3163-75. https://doi.org/10.1158/1078-0432. CCR-18-0204.

28. Sun C, Fang Y, Yin J, Chen J, Ju Z, Zhang D, Chen X, Vellano CP, Jeong KJ, Ng PK, Eterovic AKB, Bhola NH, $\mathrm{Lu}$ Y, et al. Rational combination therapy with PARP and MEK inhibitors capitalizes on therapeutic liabilities in RAS mutant cancers. Sci Transl Med. 2017; 9. https://doi. org/10.1126/scitranslmed.aal5148.

29. Murai J, Zhang Y, Morris J, Ji J, Takeda S, Doroshow JH, Pommier Y. Rationale for poly(ADP-ribose) polymerase (PARP) inhibitors in combination therapy with 
camptothecins or temozolomide based on PARP trapping versus catalytic inhibition. J Pharmacol Exp Ther. 2014; 349:408-16. https://doi.org/10.1124/jpet.113.210146.

30. Ivy SP, Liu JF, Lee JM, Matulonis UA, Kohn EC. Cediranib, a pan-VEGFR inhibitor, and olaparib, a PARP inhibitor, in combination therapy for high grade serous ovarian cancer. Expert Opin Investig Drugs. 2016; 25:597-611. https://doi. org/10.1517/13543784.2016.1156857.

31. Chou TC, Talalay P. Quantitative analysis of dose-effect relationships: the combined effects of multiple drugs or enzyme inhibitors. Adv Enzyme Regul. 1984; 22:27-55. https://doi.org/10.1016/0065-2571(84)90007-4.

32. McIlwain DR, Berger T, Mak TW. Caspase functions in cell death and disease. Cold Spring Harb Perspect Biol. 2013; 5:a008656. https://doi.org/10.1101/cshperspect.a008656.

33. Kantari C, Walczak H. Caspase- 8 and bid: caught in the act between death receptors and mitochondria. Biochim Biophys Acta. 2011; 1813:558-63. https://doi.org/10.1016/j. bbamcr.2011.01.026.

34. Refaat A, Abd-Rabou A, Reda A. TRAIL combinations: the new 'trail' for cancer therapy (Review). Oncol Lett. 2014; 7:1327-32. https://doi.org/10.3892/ol.2014.1922.

35. Sandhu SK, Schelman WR, Wilding G, Moreno V, Baird RD, Miranda S, Hylands L, Riisnaes R, Forster M, Omlin A, Kreischer N, Thway K, Gevensleben H, et al. The poly(ADP-ribose) polymerase inhibitor niraparib (MK4827) in BRCA mutation carriers and patients with sporadic cancer: a phase 1 dose-escalation trial. Lancet Oncol. 2013; 14:882-92. https://doi.org/10.1016/ S1470-2045(13)70240-7.

36. Cseh AM, Fábián Z, Sümegi B, Scorrano L. Poly(adenosine diphosphate-ribose) polymerase as therapeutic target: lessons learned from its inhibitors. Oncotarget. 2017; 8:50221-39. https://doi.org/10.18632/oncotarget.16859.

37. Scott CL, Swisher EM, Kaufmann SH. Poly (ADPribose) polymerase inhibitors: recent advances and future development. J Clin Oncol. 2015; 33:1397-406. https://doi. org/10.1200/JCO.2014.58.8848.

38. Domagala P, Huzarski T, Lubinski J, Gugala K, Domagala W. PARP-1 expression in breast cancer including BRCA1associated, triple negative and basal-like tumors: possible implications for PARP-1 inhibitor therapy. Breast Cancer Res Treat. 2011; 127:861-69. https://doi.org/10.1007/ s10549-011-1441-2.

39. Barnett JC, Bean SM, Nakayama JM, Kondoh E, Murphy SK, Berchuck A. High poly(adenosine diphosphate-ribose) polymerase expression and poor survival in advanced-stage serous ovarian cancer. Obstet Gynecol. 2010; 115:49-54. https://doi.org/10.1097/AOG.0b013e3181c2d294.

40. Veskimäe K, Staff S, Grönholm A, Pesu M, Laaksonen M, Nykter M, Isola J, Mäenpää J. Assessment of PARP protein expression in epithelial ovarian cancer by ELISA pharmacodynamic assay and immunohistochemistry. Tumour Biol. 2016; 37:11991-99. https://doi.org/10.1007/ s13277-016-5062-6.
41. Nosho K, Yamamoto H, Mikami M, Taniguchi H, Takahashi T, Adachi Y, Imamura A, Imai K, Shinomura Y. Overexpression of poly(ADP-ribose) polymerase-1 (PARP-1) in the early stage of colorectal carcinogenesis. Eur J Cancer. 2006; 42:2374-81. https://doi.org/10.1016/j. ejca.2006.01.061.

42. Barboro P, Ferrari N, Capaia M, Petretto A, Salvi S, Boccardo S, Balbi C. Expression of nuclear matrix proteins binding matrix attachment regions in prostate cancer. PARP-1: new player in tumor progression. Int $J$ Cancer. 2015; 137:1574-86. https://doi.org/10.1002/ijc.29531.

43. Mego M, Cierna Z, Svetlovska D, Macak D, Machalekova K, Miskovska V, Chovanec M, Usakova V, Obertova J, Babal P, Mardiak J. PARP expression in germ cell tumours. J Clin Pathol. 2013; 66:607-12. https://doi.org/10.1136/ jclinpath-2012-201088.

44. Donizy P, Pietrzyk G, Halon A, Kozyra C, Gansukh T, Lage H, Surowiak P, Matkowski R. Nuclear-cytoplasmic PARP-1 expression as an unfavorable prognostic marker in lymph node-negative early breast cancer: 15-year follow-up. Oncol Rep. 2014; 31:1777-87. https://doi.org/10.3892/ or.2014.3024.

45. Kaufman B, Shapira-Frommer R, Schmutzler RK, Audeh MW, Friedlander M, Balmaña J, Mitchell G, Fried G, Stemmer SM, Hubert A, Rosengarten O, Steiner M, Loman $\mathrm{N}$, et al. Olaparib monotherapy in patients with advanced cancer and a germline BRCA1/2 mutation. J Clin Oncol. 2015; 33:244-50. https://doi.org/10.1200/ JCO.2014.56.2728.

46. Alli E, Sharma VB, Sunderesakumar P, Ford JM. Defective repair of oxidative dna damage in triple-negative breast cancer confers sensitivity to inhibition of poly(ADP-ribose) polymerase. Cancer Res. 2009; 69:3589-96. https://doi. org/10.1158/0008-5472.CAN-08-4016.

47. Hastak K, Alli E, Ford JM. Synergistic chemosensitivity of triple-negative breast cancer cell lines to poly(ADP-Ribose) polymerase inhibition, gemcitabine, and cisplatin. Cancer Res. 2010; 70:7970-80. https://doi.org/10.1158/0008-5472. CAN-09-4521.

48. Ledermann JA. PARP inhibitors in ovarian cancer. Ann Oncol. 2016 (Suppl 1); 27:i40-44. https://doi.org/10.1093/ annonc/mdw094.

49. Muggia F, Safra T. 'BRCAness' and its implications for platinum action in gynecologic cancer. Anticancer Res. 2014; 34:551-56.

50. Bavi P, Jehan Z, Atizado V, Al-Dossari H, Al-Dayel F, Tulbah A, Amr SS, Sheikh SS, Ezzat A, El-Solh H, Uddin S, Al-Kuraya K. Prevalence of fragile histidine triad expression in tumors from saudi arabia: a tissue microarray analysis. Cancer Epidemiol Biomarkers Prev. 2006; 15:1708-18. https://doi.org/10.1158/1055-9965. EPI-05-0972.

51. Uddin S, Hussain AR, Siraj AK, Manogaran PS, Al-Jomah NA, Moorji A, Atizado V, Al-Dayel F, Belgaumi A, El-Solh H, Ezzat A, Bavi P, Al-Kuraya KS. Role of 
phosphatidylinositol 3'-kinase/AKT pathway in diffuse large B-cell lymphoma survival. Blood. 2006; 108:417886. https://doi.org/10.1182/blood-2006-04-016907.

52. Beg S, Siraj AK, Prabhakaran S, Jehan Z, Ajarim D, Al-Dayel F, Tulbah A, Al-Kuraya KS. Loss of PTEN expression is associated with aggressive behavior and poor prognosis in Middle Eastern triple-negative breast cancer. Breast Cancer Res Treat. 2015; 151:541-53. https://doi. org/10.1007/s10549-015-3430-3.

53. Saunus JM, Smart CE, Kutasovic JR, Johnston RL, Kalita-de Croft P, Miranda M, Rozali EN, Vargas AC, Reid LE, Lorsy E, Cocciardi S, Seidens T, McCart Reed AE, et al. Multidimensional phenotyping of breast cancer cell lines to guide preclinical research. Breast Cancer Res Treat. 2018; 167:289-301. https://doi.org/10.1007/s10549-017-4496-x.

54. Yu M, Selvaraj SK, Liang-Chu MM, Aghajani S, Busse M, Yuan J, Lee G, Peale F, Klijn C, Bourgon R, Kaminker JS, Neve RM. A resource for cell line authentication, annotation and quality control. Nature. 2015; 520:307-11. https://doi. org/10.1038/nature14397.

55. Pratheeshkumar P, Divya SP, Parvathareddy SK, Alhoshani NM, Al-Badawi IA, Tulbah A, Al-Dayel F, Siraj AK, Al-Kuraya KS. FoxM1 and $\beta$-catenin predicts aggressiveness in Middle Eastern ovarian cancer and their co-targeting impairs the growth of ovarian cancer cells. Oncotarget. 2018; 9:3590-604. https://doi.org/10.18632/ oncotarget. 23338 .
56. Siraj AK, Masoodi T, Bu R, Pratheeshkumar P, Al-Sanea N, Ashari LH, Abduljabbar A, Alhomoud S, Al-Dayel F, Alkuraya FS, Al-Kuraya KS. MED12 is recurrently mutated in Middle Eastern colorectal cancer. Gut. 2018; 67:663671. https://doi.org/10.1136/gutjnl-2016-313334.

57. Uddin S, Hussain AR, Ahmed M, Al-Dayel F, Bu R, Bavi P, Al-Kuraya KS. Inhibition of c-MET is a potential therapeutic strategy for treatment of diffuse large B-cell lymphoma. Lab Invest. 2010; 90:1346-56. https://doi. org/10.1038/labinvest.2010.108.

58. Ahmed M, Uddin S, Hussain AR, Alyan A, Jehan Z, Al-Dayel F, Al-Nuaim A, Al-Sobhi S, Amin T, Bavi P, Al-Kuraya KS. FoxM1 and its association with matrix metalloproteinases (MMP) signaling pathway in papillary thyroid carcinoma. J Clin Endocrinol Metab. 2012; 97:E113. https://doi.org/10.1210/jc.2011-1506.

59. Hussain AR, Ahmed M, Al-Jomah NA, Khan AS, Manogaran P, Sultana M, Abubaker J, Platanias LC, Al-Kuraya KS, Uddin S. Curcumin suppresses constitutive activation of nuclear factor- $\kappa \mathrm{B}$ and requires functional Bax to induce apoptosis in Burkitt's lymphoma cell lines. Mol Cancer Ther. 2008; 7:3318-29. https://doi. org/10.1158/1535-7163.MCT-08-0541. 